\title{
AKTIVITAS PENGHARUM RUANGAN MENGANDUNG MINYAK SERAI DAPUR TERHADAP PENURUNAN KOLONI BAKTERI Staphylococcus aureus DI UDARA
}

\author{
Khoirun Nisyak ${ }^{1}$, Eviomitta Rizki Amanda ${ }^{2}$, Sifa Khadrotul Azizah ${ }^{3}$ \\ ${ }^{1,2,3}$ STIKES Rumah Sakit Anwar Medika
}

Koresponden: nisachemist@gmail.com/085655099495

\begin{abstract}
Microorganism in the air is the element of pollution that is the cause of symptoms of various diseases. Microorganisms can be found in all places and survive in bad environmental conditions. One of the pathogenic bacteria found in the air is Staphylococcus aureus. This study aims to determine the effect of using air fresheners containing lemongrass essential oil on the presence of $S$. aureus bacteria in the house. The rooms of the house that were taken from the air samples included the kitchen, family room, and living room. The design used in this research is the laboratory experiment by using the air capture method. The independent variables observed included the frequency of spraying air freshener and the results were compared with a disinfectant made of $2 \%$ sodium hypochlorite solution. The S. aureus bacteria colonies obtained were in the form of golden yellow bacterial colonies, the surface was convex, purple, and cocci-shaped, which indicated the Gram-positive bacteria group. Based on the results of the study, it could be concluded that the use of air fresheners using the active ingredient of lemongrass oil did not significantly affect the decrease in the number of S. aureus bacteria colonies. However, the use of a disinfectant based on sodium hypochlorite solution as a comparison with the spraying frequency three times had an effect on decreasing the number of S.aureus bacteria colonies with the T-test results of sig value 0.007 ( $P<0.05)$.
\end{abstract}

Keywords: Air microorganism, fresheners, house, Lemongrass Oil, and Staphylococcus aureus

\begin{abstract}
ABSTRAK
Mikroorganisme di udara merupakan unsur pencemaran yang menjadi penyebab gejala berbagai penyakit. Mikroorganisme dapat ditemukan di semua tempat dan bertahan pada kondisi lingkungan yang buruk. Salah satu bakteri patogen yang banyak ditemukan di udara adalah Staphylococcus aureus. Penelitian ini bertujuan untuk mengetahui pengaruh penggunaan pengharum ruangan yang mengandung minyak atsiri serai dapur terhadap keberadaan bakteri Staphylococcus aureus di rumah. Ruangan rumah yang diambil sampel udaranya meliputi dapur, ruang keluarga, dan ruang tamu. Desain penelitian yang digunakan adalah eksperimental laboratorium dengan menggunakan metode tangkap udara. Variabel bebas yang diamati meliputi frekuensi penyemprotan pengharum ruangan dan dibandingkan hasilnya dengan desinfektan yang terbuat dari larutan natrium hipoklorit $2 \%$. Koloni bakteri $S$. aureus yang didapatkan berwujud koloni bakteri berwarna kuning keemasan, permukaannya berbentuk cembung, berwarna ungu, dan berbentuk kokus, dimana menunjukkan golongan bakteri Gram positif. Berdasarkan hasil penelitian dapat disimpulkan bahwa penggunaan pengharum ruangan menggunakan bahan aktif minyak serai dapur tidak berpengaruh secara signifikan terhadap penurunan jumlah koloni bakteri $S$. aureus. Namun penggunaan desinfektan berbahan dasar larutan natrium hipoklorit sebagai pembanding dengan frekuensi
\end{abstract}


penyemprotan tiga kali berpengaruh terhadap penurunan jumlah koloni bakteri $S$. aureus dengan hasil uji T nilai sig $0.007(\mathrm{P}<0.05)$.

Kata kunci: mikroorganisme udara, pengharum ruangan, rumah, minyak serai dapur, dan Staphylococcus aureus

\section{PENDAHULUAN}

Keberdaan mikroorganisme di udara merupakan salah satu unsur pencemaran yang menjadi penyebab gejala berbagai penyakit. Pertumbuhan bakteri di tempat umum atau ruang publik dipengaruhi oleh sistem ventilasi, kelembapan udara, aliran udara, jenis mikroorganisme, partikel debu, dan temperatur. Pada temperatur optimum pertumbuhan bakteri sangat tinggi karena akan menginaktifasi sistem enzimatik dalam sel bakteri (Huang, 2017). Keberadaan mikroorganisme dalam suatu ruangan dipengaruhi oleh beberapa faktor, antara lain padatnya orang dan kegiatan orang yang menempati ruangan (Astriani et $a l ., 2012)$. Salah satu bakteri patogen yang terdapat di udara adalah Staphylococcus aureus. Keberadaan bakteri S. aureus di udara sebagai indikator tercemarnya makanan yang dipengaruhi oleh tidak terjaganya kebersihan, dan udara ruangan yang lembab (Horváth et al., 2016).

Kontaminasi bakteri $S$. aureus dapat menyebabkan sejumlah infeksi seperti alergi, radang tenggorokan, asma, dan infeksi nosokomial (Sharma et al., 2017). Dua dari empat isolate koloni bakteri udara merupakan bakteri $S$. aureus dengan warna koloni berwarna krem dan bentuk koloni bulat (Todar, 2008). Hasil pengujian biokimia dan pewarnaan gram menunjukan bakteri gram positif $S$. aureus dengan bentuk koloni coccus berwarna ungu dan hasil uji biokimia meliputi uji indol positif, uji sukrosa positif, uji glukosa positif, uji laktosa positif, dan uji katalase positif.

Upaya mengurangi perkembangan bakteri patogen dan mengurangi besarnya kasus infeksi akibat bakteri patogen maka dapat digunakan bahan antibakteri. Salah satu bahan antibakteri yang dapat digunakan adalah minyak atsiri. Minyak atsiri diketahui mampu menghambat pertumbuhan bakteri dengan cara mengganggu proses pembentukan membran atau dinding sel bakteri (Solórzano-Santos and Miranda-Novales, 2012). Salah satu cara untuk mengurangi penyebaran bakteri patogen dalam udara dapat dilakukan dengan penyemprotan pengharum ruangan yang mengandung minyak atsiri sebagai antibakteri di udara.

Pengharum ruangan dipercaya dapat membunuh mikroorganisme sekaligus menghilangkan sumber bau. Penggunaan pengharum ruangan sebagai bahan antibakteri dapat menyebabkan penurunan aktivitas antibakteri serta lebih mudah dilakukan, lebih praktis, dan biayanya lebih hemat (Filiptsova et al., 2017). Minyak atsiri yang digunakan dalam penelitian ini adalah minyak serai dapur yang diisolasi dari tanaman serai dapur (Cymbopogon citratus) dengan metode distilasi uap. Minyak serai dapur mempunyai komponen penyusun utama yaitu geranial ( sitral $\alpha$ ) sebesar 42,11\%, neral (sitral $\beta$ ) sebesar $34,78 \%$, dan mirsen sebesar $13,71 \%$ (Venzon et al., 2018). Mekanisme kerja minyak serai dapur sebagai antibakteri untuk menghambat pertumbuhan bakteri adalah membentuk senyawa komplek dengan protein ekstraseluler yang terlarut sehingga dapat merusak membran sel bakteri (Zhang et al., 2017). Berdasarkan penelitian yang dilakukan Nisyak (2018) terkait aktivitas antibakteri minyak serai dapur pada bakteri Staphylococcus aureus menggunakan diffuser menunjukkan penurunan jumlah koloni $S$. aureus setelah penggunaan minyak atsiri dalam jangka waktu 48 jam. Berdasarkan hasil tersebut dapat disimpulkan bahwa minyak serai dapur memiliki kemampuan untuk menekan pertumbuhan bakteri $S$. aureus di udara. Tujuan penelitian ini adalah untuk 
mengetahui efektivitas penggunaan pengharum ruangan yang mengandung minyak serai dapur terhadap keberadaan koloni bakteri $S$. aureus di rumah. Berdasarkan studi literatur dan uji pendahuluan, hipotesis dari penelitian ini adalah minyak serai dapur yang diaplikasikan sebagai pengharum ruangan dapat menekan jumlah koloni bakteri $S$. aureus di udara kawasan rumah.

\section{METODE}

\section{Desain, tempat, dan waktu}

Desain penelitian yang digunakan Eksperimental laboratorium. Penelitian dilakukan di Laboratorium Mikrobiologi STIKES Rumah Sakit Anwar Medika untuk identifikasi kualitatif dan kuantitatif bakteri $S$. aureus dan rumah peneliti sebagai tempat pengambilan sampel mikroorganisme udara. Penelitian ini dilakukan dalam jangka waktu 5 bulan yakni bulan April - Agustus tahun 2020

\section{Bahan dan alat}

Bahan yang digunakan dalam penelitian antara lain adalah media Manittol Salt Agar (MSA), media Eosin Methylene Blue Agar (EMB), media Nutrient Agar (NA), aquades, pemutih pakaian dengan kandungan $\mathrm{NaClO}$ sebesar 5\%, minyak serai dapur, dan baking soda. Peralatan yang digunakan meliputi cawan petri, labu ukur, pipet tetes, neraca analitik, colony counter, bak pewarnaan gram, dan inkubator.

\section{Identifikasi awal bakteri $S$. aureus di ruangan rumah}

Identifikasi awal jumlah koloni bakteri $S$. aureus dalam rumah dilakukan dengan metode tangkap udara (Astriani et al., 2012). Cawan Petri yang berisi $15 \mathrm{~mL}$ media Manitol Salt Agar (MSA) digunakan sebagai media selektif untuk menumbuhkan bakteri S. aureus. Cawan petri yang berisi media MSA diletakkan di sudut ruang dengan kondisi terbuka selama 15-30 menit. Cawan Petri tersebut kemudian ditutup dan diinkubasi selama 24 jam didalam inkubator pada temperatur 37 ${ }^{\circ} \mathrm{C}$. Pada tahap selanjutnya dilakukan uji kuantitatif dengan menghitung koloni menggunakan colony counter.

Koloni diambil untuk dilakukan uji kualitatif dengan metode pewarnaan Gram dengan menginokulasikan bakteri ke kaca objek dengan menambahkan kristal violet dan diamkan selama dua menit, lalu dibilas dengan air mengalir. Tahap selanjutnya ditambahkan larutan lugol, didiamkan selama dua menit, dan dibilas dengan air mengalir. Kemudian sediaan dibilas dengan alkohol selama 10-20 detik dan dibilas dengan air mengalir. Tahap terakhir dilakukan penambahan safranin dan dibiarkan selama satu menit lalu dibilas dengan air mengalir. Kaca objek yang sudah siap diidentifikasi dengan mikroskop perbesaran rendah. Perbesaran dilakukan secara bertahap hingga didapatkan bentuk coccus berwarna ungu (Gram positif).

Identifikasi selanjutnya adalah uji katalase dilakukan dengan mengambil sedikit koloni dari media MSA dan koloni diletakkan pada objek glass yang telah ditetesi $\mathrm{H}_{2} \mathrm{O}_{2}$. Hasil positif ditandai dengan adanya gelembung udara. Identifikasi terakhir yaitu uji koagulase dengan plasma sitrat, dimana diteteskan plasma sitrat dan natrium sitrat $0,9 \%$ ke objek glass masingmasing satu tetes, kemudian diambil koloni yang tumbuh pada media MSA dengan jarum ose dan lakukan homogenisasi. Hasil dari uji koagulase dapat dilihat ada tidaknya gumpalan, dimana hasil positif koagulase ditandai tidak adanya gumpalan menandakan bakteri yang diuji positif Staphylococcus aureus. Hasil uji kuantitatif dan kualitatif digunakan sebagai dasar kondisi awal penyebaran mikroba dalam udara rumah.

\section{Pembuatan Pengharum Ruangan Minyak Serai Dapur}

Pengharum ruangan dibuat dengan konsentrasi 2,5\%, dimana 6,25 mL minyak serai dapur dengan 10 gram baking soda dicampurkan dalam gelas piala. 
Selanjutnya campuran tersebut dimasukkan ke dalam botol spray berwarna gelap. Sebanyak $250 \mathrm{~mL}$ aquades ditambahkan kedalam botol spray dan dihomogenkan. Pengharum ruangan tersebut siap digunakan untuk penelitian.

\section{Pembuatan Desinfektan berbahan pemutih pakaian}

Sebanyak $20 \mathrm{~mL}$ pemutih pakaian dengan kadar hipokolorit 5,25\% dicampurkan dengan $1 \mathrm{~L}$ aquades kemudian dihomogenkan. Campuran tersebut dimasukkan ke botol semprot.

Uji antibakteri pengharum ruangan minyak serai dapur dan desinfektan

Bahan aktif yang digunakan sebagai antibakteri meliputi minyak serai dapur dan desinfektan. Metode analisa bakteri $S$. aureus yang ada dalam ruangan dilakukan dengan metode tangkap udara menggunakan prosedur yang sama dengan identifikasi awal mikroba dalam ruang rumah. Penyemprotan pengharum ruangan minyak serai dapur dan desinfektan dilakukan variasi frekuesi penyemprotannya dalam jangka waktu 24 jam. Frekuesi penyemprotannya sebanyak satu kali, dua kali, dan tiga kali.

\section{Pengolahan dan Analisa Data}

Data yang didapatkan dari penelitian meliputi data penurunan jumlah koloni S.aureus dihubungkan dengan waktu dan durasi penyemprotan, didapatkan data kualitatif dan kuantitatif berupa jumlah koloni bakteri $S$. aureus. Data yang diperoleh dianalisa dengan metode regresi berganda menggunakan bantuan perangkat lunak SPSS dengan menghitung uji $F$ dan Uji T. Uji $F$ digunakan untuk mengetahui pengaruh semua variabel bebas secara bersama-sama terhadap variabel terikat. Sedangkan uji T digunakan untuk mengetahui masingmasing variabel bebas terhadap variabel terikat.

\section{HASIL \\ Identifikasi koloni $S$. aureus di ruangan rumah}

Identifikasi awal jumlah koloni $S$. aureus dalam ruangan rumah dilakukan pada lima ruangan dalam rumah yaitu dapur, ruang keluarga, dan ruang tamu, teras, dan kamar mandi. Berdasarkan hasil pengamatan menunjukkan bahwa koloni mikroorganisme pada udara ruang berbentuk bulat, berwarna putih kekuningan, permukaan cembung dan dapat mengubah warna media MSA. Hal ini menunjukkan bakteri tersebut mampu memfermentasi manitol, karena adanya fenol acid pada media MSA sehingga bakteri mampu merubah warna merah pada media menjadi kuning sedangkan jika hasil negatif maka tidak ada perubahan warna (Toelle dan Lenda, 2014).

Tahap selanjutnya dilakukan uji kuantitatif dengan menghitung koloni yang tumbuh dan sesuai ciri morfologi bakteri $S$. aureus menggunakan colony counter. Berdasarkan lima sampel ruangan yang diidentifikasi hanya terdapat tiga sampel yang digunakan penelitian karena kamar mandi tidak terdapat pertumbuhan koloni dan teras menjadi tempat yang jarang digunakan. Data perhitungan jumlah koloni bakteri S. aureus disajikan pada Tabel 1 . Pada Tabel 1 menunjukkan bahwa ruangan yang paling banyak jumlah koloni $S$. aureus adalah dapur. Pada penelitian ruangan yang difokuskan untuk pengambilan sampel udara adalah dapur, ruang tamu, dan ruang keluarga.

Identifikasi mikroorganisme secara historis didasarkan pada beberapa karakter termasuk ciri morfologi dan berbagai reaksi biokimia. Untuk mengetahui golongan bakteri tersebut maka harus melakukan pewarnaan Gram dan pengamatan bentuk pada koloni secara mikroskopis. Hasil sampel pewarnaan gram yang termasuk dalam bakteri $S$. aureus diamati di bawah mikroskop menunjukkan hasil bentuk coccus dan tergolong Gram positif yang 
berwarna ungu, ditunjukkan pada Gambar 2. Hal ini menunjukkan bahwa bakteri tersebut tergolong kedalam bakteri Gram positif karena bakteri Gram positif dapat menyerap zat warna kristal violet yang berwarna ungu.

Pada penelitian ini ditemukan bakteri berbentuk bulat yang berarti termasuk ke dalam bakteri golongan kokus. Hasil ini sesuai dengan pernyataan Bhattacharjee et al., (2010), yang menyatakan bahwa bakteri S.aureus merupakan golongan bakteri Gram positif berbentuk kokus yang tersusun seperti anggur. Bakteri Gram positif berbentuk kokus dimungkinkan bakteri golongan Staphylococcus atau Streptococcus. Maka untuk mengetahui secara pasti bakteri termasuk kedalam golongan spesies bakteri tersebut dilakukan uji katalase. Hasil uji mikroskopis ditunjukkan pada Gambar 1.

Hasil penelitian dari uji katalase menunjukkan terbentuknya gelembung udara. Uji katalase berguna dalam mengidentifikasi kelompok bakteri tertentu. Uji katalase pada bakteri bentuk kokus digunakan untuk membedakan Staphylococcus dan Streptococcus. Kelompok Streptococcus memberi reaksi negatif pada uji katalase, sedangkan Staphylococcus memberikan reaksi positif (Wongsariya et al., 2014). Katalase merupakan enzim yang mengkatalisa penguraian hidrogen peroksida menjadi $\mathrm{H}_{2} \mathrm{O}$ dan $\mathrm{O}_{2}$. Hidrogen peroksida bersifat toksik terhadap sel karena bahan ini menginaktifkan enzim dalam sel. Hidrogen peroksida terbentuk sewaktu metabolisme aerob, sehingga mikroorganisme yang tumbuh dalam lingkungan aerob pasti menguraikan bahan tersebut. Hasil uji katalase ditunjukkan pada Gambar 2.

Uji lanjutan selanjutnya adalah uji koagulase dengan cara meneteskan darah manusia ke plat tetes, diambil suspensi bakteri lalu kedua suspensi dicampur dan dihomogenkan. Reaksi positif terjadi apabila dalam waktu 2-3 menit terbentuk presipitat granular (Delfira dkk., 2020). Hasil penelitian dari tiga sampel di media MSA menunjukan hasil positif ditandai adanya gumpalan. Fungsi uji koagulase untuk membedakan $S$. aureus dengan spesies Staphylococus yang lainnya. Uji koagulase bertujuan untuk mengetahui kemampuan bakteri menghasilkan enzim koagulase. Koagulase merupakan protein ekstraseluler yang dihasilkan oleh $S$. aureus yang dapat menggumpalkan plasma dengan bantuan faktor yang terdapat dalam serum. Faktor serum bereaksi dengan koagulase untuk membentuk esterase, aktivasi penggumpalan, dan mengaktivasi protombin menjadi trombin. Trombin akan membentuk fibrin yang berpengaruh terhadap terjadinya penggumpalan plasma. Kemampuan menggumpalkan plasma merupakan salah satu faktor verulensi dalan potogenesis S. aureus (Ote et al., 2011). Hasil uji koagulase ditunjukkan pada Gambar 3.

\section{Aktivitas Pengharum Ruangan Minyak Serai Dapur terhadap Koloni Bakteri $S$. aureus}

Pembuatan pengharum ruangan dibuat dengan konsentrasi 2,5\% minyak serai dapur. Penambahan baking soda dalam pengharum ruangan berfungsi sebagai penyerap bau tidak sedap di udara dan untuk menyegarkan udara (Faidliyah, 2017). Minyak serai dapur memiliki aktivitas antimikroba. Efektifitas dari minyak atsiri serai dapur dipengaruhi oleh kompisisi senyawa yang terkandung. Kandungan senyawa kimia dari minyak serai dapur meliputi senyawa geranial, neral dan mirsen yang termasuk dalam golongan senyawa aldehid yang memiliki gugus fungsional karbonil yang terikat pada rantai karbon di satu sisi dan atom hidrogen di sisi yang lain (Sritabutra and Soonwera, 2013). Sitral adalah nama diberikan untuk campuran bahan isomer dari neral dan geranial (Gambar 4). Efek antimikroba dari sitral cukup baik, tetapi mekanisme 
hambatan pertumbuhan tidak sepenuhnya dipahami (Oladeji et al., 2019).

Hasil pengamatan jumlah koloni dengan perlakuan penyemprotan pengharum ruangan berbahan aktif minyak serai dapur dapat dilihat pada Tabel 2. Analisis data menggunakan perangkat lunak SPPS disajikan pada Tabel 3, dimana uji $\mathrm{T}$ diatas tidak bekerja secara maksimal. Data diatas menunjukkan bahwa nilai Sig durasi penyemprotan sebesar 0.83 $(\mathrm{P}>0.05)$. Hipotesis ditolak artinya frekuensi penyemprotan tidak berpengaruh signifikasi terhadap jumlah koloni. Sedangkan nilai Sig lama penyemprotan sebesar $0.631 \quad(\mathrm{P}>0.05)$ maka hipotesis ditolak artinya lama penyemprotan tidak berpengaruh signifikasi terhadap jumlah koloni. Hasil uji $\mathrm{F}$ nilai sig sebesar 0.183 $(\mathrm{P}>0.05)$ artinya frekuensi penyemprotan dan lama penyemprotan tidak berpengaruh tehadap jumlah koloni.

Pada ruang keluarga dilihat pada Tabel 3 uji $\mathrm{T}$ data menunjukkan nilai sig durasi penyemprotan sebesar $1000 \quad(\mathrm{P}>0.05)$. Hipotesis ditolak artinya frekuensi penyemprotan tidak berpengaruh signifikasi terhadap jumlah koloni. Sedangkan nilai Sig lama penyemprotan $0.041 \quad(\mathrm{P}>0.05)$ maka hipotesis ditolak artinya lama penyemprotan tidak berpengaruh signifikasi terhadap jumlah koloni. Hasil uji F nilai sig $0.105(\mathrm{P}>0.05)$ artinya frekuensi penyemprotan dan lama penyemprotan tidak berpengaruh tehadap jumlah koloni.

Pada ruang tamu dapat dilihat pada Tabel 3 uji $\mathrm{T}$ menunjukkan nilai Sig frekuensi penyemprotan sebesar 0.688 $(\mathrm{P}>0.05)$. Hipotesis ditolak artinya durasi penyemprotan tidak berpengaruh signifikasi terhadap jumlah koloni. Nilai Sig lama penyemprotan 0.691 ( $\mathrm{P}>0.05$ ). Hipotesis ditolak artinya lama penyemprotan tidak berpengaruh terhadap jumlah koloni. Hasil uji $\mathrm{F}$ menunjukkan nilai Sig $0.843(\mathrm{P}>0.05)$ artinya frekuensi penyemprotan dan lama penyemprotan tidak bepengaruh signifikasi terhadap jumlah koloni.

$\begin{array}{lrr}\text { Aktivitas } & \text { desinfektan } & \text { terhadap } \\ \text { penurunan } & \text { koloni } & \text { bakteri } \\ \text { Staphylococcus aureus } & \end{array}$

Pada penelitian menggunakan desinfektan dari pemutih pakaian yang mengandung senyawa natrium hipoklorit sebagai kontrol positif. Desinfektan bersifat biodegradable, memiliki kemampuan menghilangkan bau yang kurang sedap, tidak meninggalkan noda, stabil, mudah digunakan, dan ekonomis. Natrium hipoklorit jika dilarutkan dalam air menimbulkan efek pemurnian permukaan, penghilang bau, dan desinfektan.

Hasil pengamatan jumlah koloni $S$. aureus dengan perlakuan desinfektan berbahan aktif minyak serai dapur pada ruang dapur dapat dilihat pada Tabel 4 . Analisis data hasil penelitian menggunakan perangkat lunak SPPS ditunjukkan pada Tabel 5, dimana uji $\mathrm{T}$ diatas tidak bekerja secara maksimal. Data diatas menunjukkan bahwa nilai Sig frekuensi penyemprotan sebesar $0.011(\mathrm{P}>0.05)$. Hipotesis ditolak artinya frekuensi penyemprotan tidak berpengaruh signifikasi terhadap jumlah koloni. Sedangkan nilai Sig lama penyemprotan sebesar $0.271 \quad(\mathrm{P}>0.05)$ maka hipotesis ditolak artinya lama penyemprotan tidak berpengaruh signifikasi terhadap jumlah koloni. Hasil uji F nilai sig sebesar $0.024(\mathrm{P}>0.05)$ artinya frekuensi penyemprotan dan lama penyemprotan tidak berpengaruh tehadap jumlah koloni.

Pada ruang keluarga dilihat pada Tabel 5 uji $\mathrm{T}$ data menunjukkan nilai sig Frekuensi penyemprotan sebesar 0.013 $(\mathrm{P}>0.05)$. Hipotesis ditolak artinya durasi penyemprotan tidak berpengaruh signifikasi terhadap jumlah koloni. Sedangkan nilai Sig lama penyemprotan 0.107 ( $>>0.05)$ maka hipotesis ditolak artinya lama penyemprotan tidak berpengaruh signifikasi terhadap jumlah koloni. Hasil uji F nilai sig $0.21(\mathrm{P}>0.05)$ 
artinya frekuensi penyemprotan dan lama penyemprotan tidak berpengaruh tehadap jumlah koloni.

Pada ruang tamu dapat dilihat pada Tabel 5 uji $\mathrm{T}$ menunjukkan nilai $\mathrm{Sig}$ frekuensi penyemprotan sebesar 0.349 $(\mathrm{P}>0.05)$. Hipotesis ditolak artinya frekuensi penyemprotan tidak berpengaruh signifikasi terhadap jumlah koloni. Nilai Sig lama penyemprotan $0.007 \quad(\mathrm{P}<0.05)$. Hipotesis diterima artinya lama penyemprotan berpengaruh terhadap penurunan jumlah koloni. Hasil uji $F$ menunjukkan nilai Sig $0.017 \quad(\mathrm{P}>0.05)$ artinya frekuensi penyemprotan dan lama penyemprotan tidak bepengaruh signifikasi terhadap jumlah koloni.

\section{PEMBAHASAN}

Berdasarkan Gambar 5 diketahui bahwa hasil nilai rata-rata pada ketiga titik penyemprotan, pada dapur frekuensi penyemprotan 1 kali, 2 kali, dan 3 kali mengalami penurunan. Pada ruang keluarga frekuensi penyemprotan 1 kali 2 kali 3 kali mengalami penurunan. Pada ruang tamu durasi penyemprotan 1 kali 2 kali 3 kali jumlah koloni tidak mengalami perubahan Hal ini disebabkan karena adanya faktor yang mempengaruhi yaitu banyaknya aktivitas manusia, udara yang lembab, dan kurangnya menjaga kebersihan.

$$
\text { Rahman (2014) melaporkan }
$$

bioaktifitas minyak serai dapur terhadap pertumbuhan bakteri $S$. aureus dan E. coli, diperoleh bahwa minyak atsiri tersebut lebih efektif dalam menghambat pertumbuhan bakteri Gram positif $S$. aureus bila dibandingkan dengan Gram negatif Escherichia coli. Efektivitas minyak serai dapur diperoleh pada konsentrasi 50\% terhadap bakteri Escherichia coli dan $S$. aureus.

Minyak serai dapur lebih efektif dalam menghambat pertumbuhan bakteri gram positif dibandingkan gram negatif. Hal ini disebabkan kemampuan biologis yang dimiliki oleh kedua bakteri sangat berbeda. Struktur dinding sel bakteri gram positif yang relatif lebih sederhana sehingga memudahkan senyawa antibakteri masuk ke dalam sel dan menemukan sasaran untuk bekerja. Mekanisme kerja terpenoid sebagai antibakteri melibaktan kerusakan membran oleh senyawa lipofilik. Terpenoid dapat bereaksi dengan protein transmembran pada membran luar dinding sel bakteri. Akibatnya sel bakteri kekurangan nutrisi dan pertumbuhannya akan terhambat atau mati (Amalia dkk, 2017).

Mekanisme antibakteri dari minyak atsiri adalah mengubah permeabilitas membran sel, menghilangkan ion-ion dalam sel, menghalangi proton-pump, dan menurunkan produksi adenosin trifosfat (ATP) merupakan mekanisme kerja minyak atsiri untuk membunuh bakteri. Mekanisme kerja minyak atsiri adalah dengan menghambat membran sel bakteri sehingga menyebabkan material sitoplasma menghilang. Minyak atsiri bersifat lipofilik yang dapat melewati dinding bakteri karena dinding bakteri terdiri meliputi polisakarida, asam lemak, dan fosfolipid. Hal ini dapat mengakibatkan kerusakan dinding sel sehingga dapat membunuh bakteri (Korenblum et al., 2013).

Berdasarkan Gambar 6 diketahui bahwa semakin meningkat frekuesi penyemprotan desinfektan pada area dapur dan ruang tengah, jumlah koloni bakteri $S$. aureus semakin meningkat. Sedangkan pada ruang tamu terjadi penurunan jumlah koloni $S$. aureus. Hal tersebut menunjukkan desinfektan tidak bekerja secara maksimal. Faktor yang mempengaruhi meningkatnya jumlah koloni $S$. aureus yaitu kurangnya ventilasi di ruangan, kelembaban udara, aktivitas manusia, dan kurangnya menjaga kebersihan.

Menurut penelitian Ghanem et al (2012) mekanisme kerja desinfektan dalm membunuh bakteri dengan mengubah permeabilitas membran sel bakteri. 
membran sel berguna sebagai penghalang selektif terhadap zat terlarut dan menahan zat yang tidak larut. Beberapa zat diangkut secara aktif melalui membran, sehingga konsentrasinya dalam sel tinggi. Zat-zat yang terkonsentrasi pada permukaan sel akan mengubah sifat-sifat fisiknya sehingga membunuh dan menghambat sel. Perubahan permeabilitas membran sel bakteri merupakan mekanisme kerja fenol, dan senyawa amonium kuartener. Terjadinya perubahan permeabilitas membran sel menyebabkan kebocoran kostituen sel yang esensial sehingga bakteri mengalami kematian. Interkalasi dalam asam deoksiribo nukleat (ADN) senyawa turunan trifenilmetan seperti gentian violet dan akridin seperti akriflavin bekerja sebagai antibakteri dengan mengikat secara kuat asam nukleat. Ikatan ini akan menghambat sintesis ADN sehingga sintesis protein tidak terjadi.

Menurut penelitian Ningrum (2017) melaporkan bahwa ketika natrium hipoklorit larut dalam air, dua zat akan akan terbentuk yaitu asam hipoklorit dan ion hipoklorit. Asam hipoklorit terdegradasi membentuk asam klorida dan oksigen. Oksigen merupakan oksidator yang sangat kuat oleh karena itu natrium hipoklorit sering digunakan untuk membunuh bakteri. Larutan asam klorit mampu mengoksidasi dan menghidrolasi sel dan secara osmosis mengalirkan air keluar dari sel akibat sifatnya yang hipertonis. Natrium hipoklorit mempunyai pH antara 11-12.

Berdasarkan penelitian yang telah dilakukan hasil uji linear berganda menggunakan uji $\mathrm{T}$ dan uji $\mathrm{F}$. Uji T untuk mengetahui pengaruh masing-masing variabel bebas terhadap variabel terikat. Berdasarkan uji tersebut pada penyemprotan minyak serai dapur hipotesis ditolak artinya variabel bebas dan variabel terikat tidak berpengaruh signifikasi secara bersama-sama terhadap jumlah koloni. Hal ini dikarenakan konsentrasi minyak serai dapur yang digunakan terlalu kecil.

\section{KESIMPULAN}

Berdasarkan penelitian yang telah dilakukan dapat disimpulkan bahwa penggunaan pengharum ruangan minyak serai dapur dan desinfektan belum bekerja maksimal terhadap penurunan jumlah koloni bakteri $S$. aureus dalam udara di ruangan rumah. Namun penggunaan desinfektan dengan frekuensi penyemprotan tiga kali berpengaruh terhadap penurunan jumlah koloni bakteri S. aureus dengan hasil uji T nilai sig 0.007 $(\mathrm{P}<0.05)$.

\section{SARAN}

Berdasarkan hasil penelitian yang diperoleh, penulis menyarankan penggunaan pengharum minyak serai dapur sebagai antibakteri dibuat dengan konsentrasi lebih pekat dan frekuensi penyemprotan yang lebih banyak.

\section{UCAPAN TERIMA KASIH}

Penulis mengucapkan terima kasih kepada STIKES Rumah Sakit Anwar Medika yang telah memberikan dukungan materi terhadap kelancaran proses penelitian.

\section{DAFTAR PUSTAKA}

Astriani, N. K., Sunarni, T. and Rinanto, Y. (2012) 'Pengujian Resistensi Staphylococcus aureus Hasil Isolasi Udara Ruang Kelas Sekolah Dasar Di Surakarta terhadap Penisilin G , Metisilin dan Vankomisin Staphylococcus aureus Resistance Testing of Insulation Air in the Surakarta Elementary School Classroom t', 9(1).

Bhattacharjee, I., Chatterjee, S. K. and Chandra, G. (2010) 'Isolation and identification of antibacterial components in seed extracts of Argemone mexicana L. (Papaveraceae)', Asian Pacific Journal of Tropical Medicine. Hainan Medical College, 3(7), pp. 547-551. doi: 10.1016/S1995-7645(10)60132- 
0.

Filiptsova, O. V. et al. (2017) 'The effect of the essential oils of lavender and rosemary on the human short-term memory', Alexandria Journal of Medicine. Alexandria University Faculty of Medicine, pp. 3-6. doi: 10.1016/j.ajme.2017.05.004.

Horváth, G. et al. (2016) Natural Substances from Higher Plants as Potential Anti-MRSA Agents, Studies in Natural Products Chemistry. Elsevier B.V. doi: 10.1016/B978-0444-63603-4.00003-6.

Huang, L. (2017) 'Dynamic identification of growth and survival kinetic parameters of microorganisms in foods', Current Opinion in Food Science. Elsevier Ltd, 14, pp. 85-92. doi: 10.1016/j.cofs.2017.01.013.

Oladeji, O. S. et al. (2019) 'Phytochemistry and pharmacological activities of Cymbopogon citratus: A review', Scientific African. Elsevier B.V., 6, p. e00137.

doi: 10.1016/j.sciaf.2019.e00137.

Sharma, G. et al. (2017) 'Inhibitory effect of cinnamaldehyde alone and in combination with thymol, eugenol and thymoquinone against Staphylococcus epidermidis', Journal of Herbal Medicine. Elsevier GmbH., 9, pp. 6873. doi: 10.1016/j.hermed.2016.11.001.

Solórzano-Santos, F. and MirandaNovales, M. G. (2012) 'Essential oils from aromatic herbs as antimicrobial agents', Current Opinion in Biotechnology, 23(2), pp. 136-141. doi: 10.1016/j.copbio.2011.08.005.

Sritabutra, D. and Soonwera, M. (2013) 'Repellent activity of herbal essential oils against Aedes aegypti (Linn.) and Culex quinquefasciatus (Say.)', Asian Pacific Journal of Tropical Disease, 3(4), pp. 271-276. doi: 10.1016/S2222-1808(13)60069-9.

Todar, S. (2008) 'Staphylococcus aureus yang Dilihat dari Mikroskop Elektron. Sumber Todar, 2008'.

Venzon, L. et al. (2018) 'Essential oil of Cymbopogon citratus (lemongrass) and geraniol, but not citral, promote gastric healing activity in mice', Biomedicine and Pharmacotherapy. Elsevier, 98(May 2016), pp. 118-124. doi: 10.1016/j.biopha.2017.12.020.

Wongsariya, K. et al. (2014) 'Synergistic interaction and mode of action of Citrus hystrix essential oil against bacteria causing periodontal diseases', Pharmaceutical Biology, 52(3), pp. 273-280. doi: $10.3109 / 13880209.2013 .833948$.

Zhang, Y. et al. (2017) 'Antibacterial and antibiofilm activities of eugenol from essential oil of Syzygium aromaticum (L.) Merr. \& L. M. Perry (clove) leaf against periodontal pathogen Porphyromonas gingivalis', Microbial Pathogenesis. Elsevier Ltd, 113(October), pp. 396-402. doi: 10.1016/j.micpath.2017.10.054. 

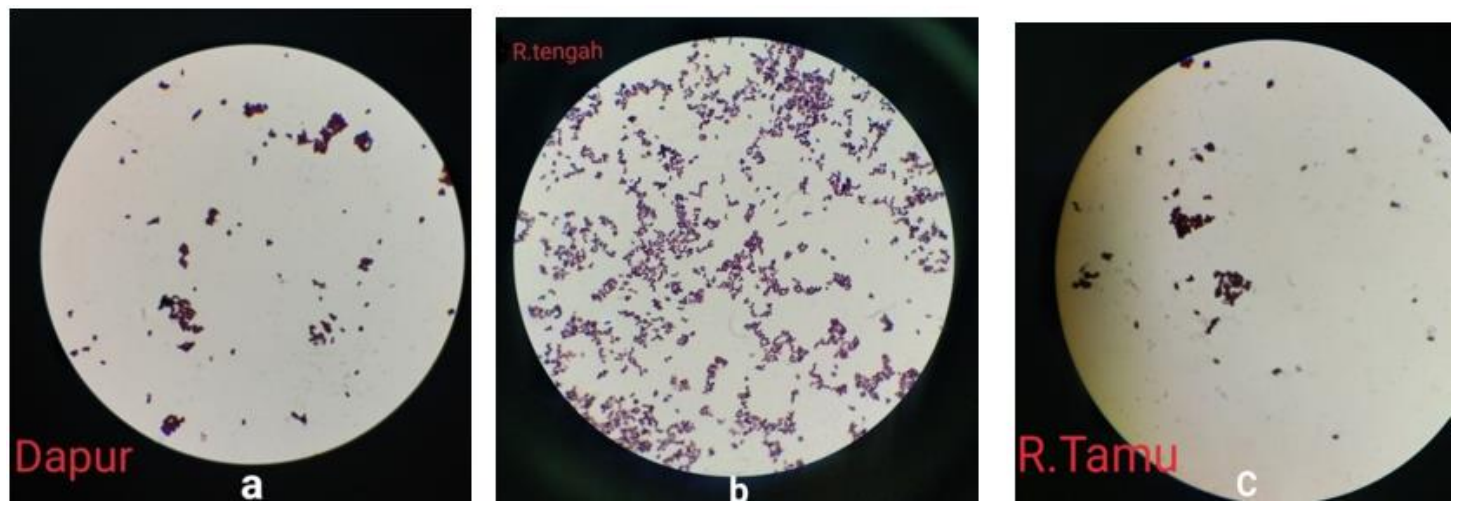

Gambar 1. Pengamatan makroskopis koloni bakteri S. aureus

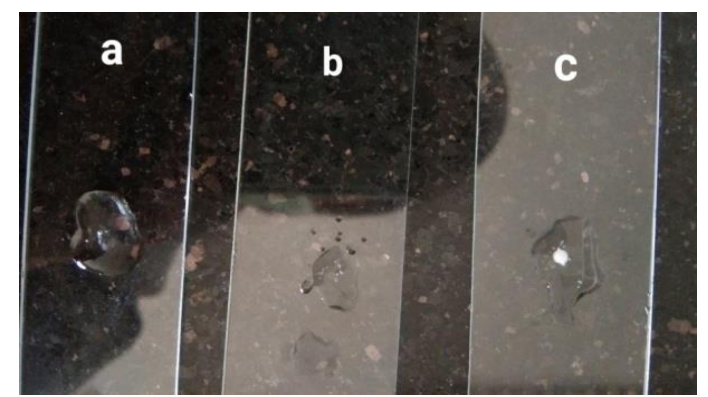

Gambar 2. Hasil uji katalase isolat koloni bakteri S. aureus yang terdapat dalam udara rumah (a) dapur (b) ruang keluarga (c) ruang tamu

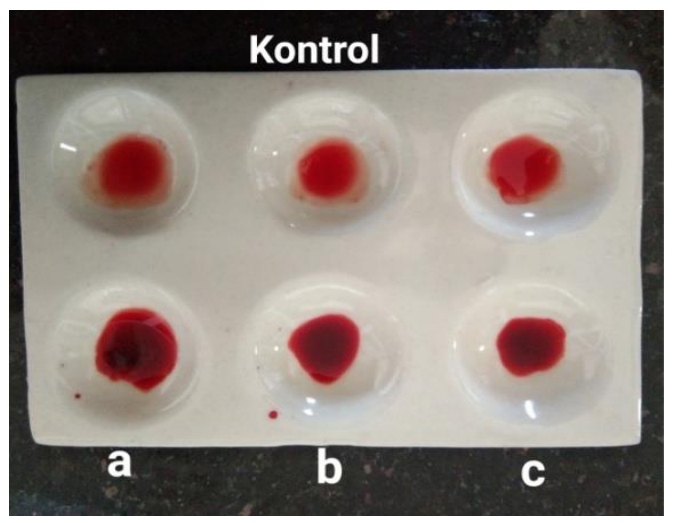

Gambar 3. Hasil uji koagulase isolat koloni bakteri S. aureus yang terdapat dalam udara rumah (a) dapur (b) ruang keluarga (c) ruang tamu 


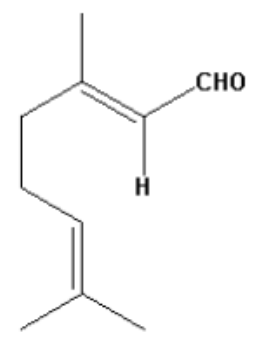<smiles>C=C(C)CCC=C(C)C</smiles>

Gambar 4. Struktur senyawa sitral dalam minyak serai dapur

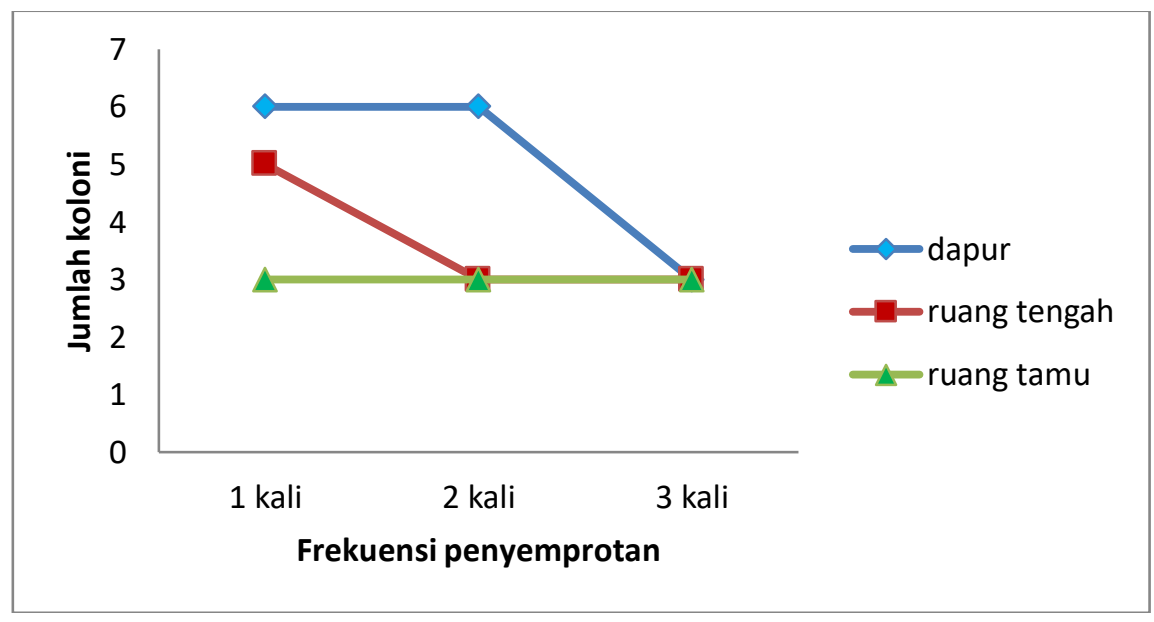

Gambar 5. Aktivitas pengharum ruangan minyak serai dapur terhadap kolono bakteri S. aureus di udara

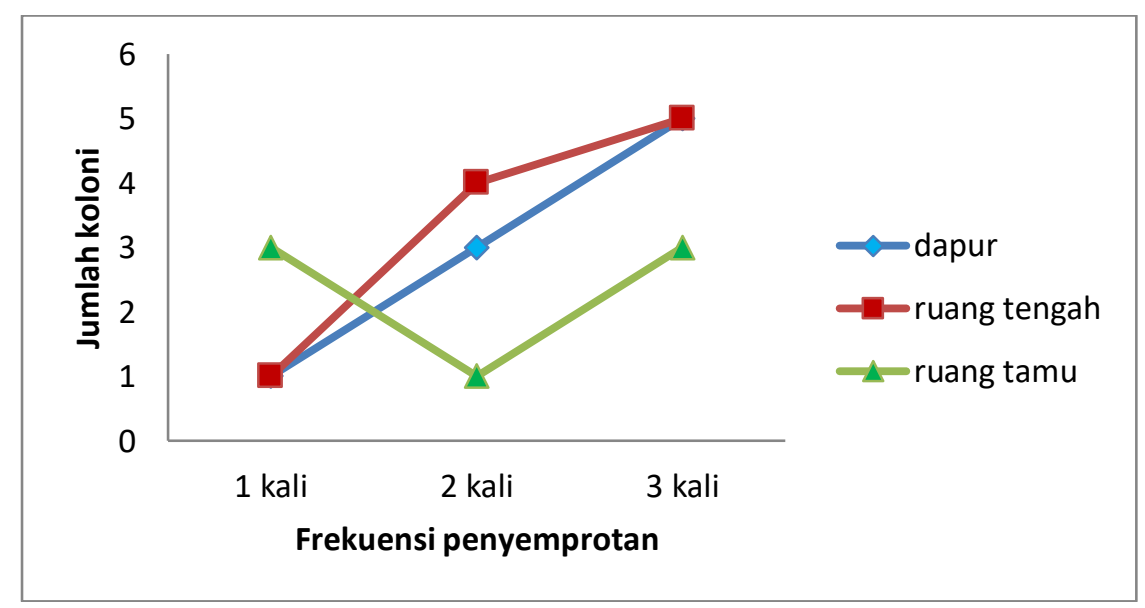

Gambar 6. Aktivitas desinfektan terhadap koloni bakteri S. aureus di udara 
Tabel 1. Jumlah koloni bakteri S.aureus pada ruangan di rumah

\begin{tabular}{ccc}
\hline No & Ruangan & Jumlah Koloni \\
\hline 1 & Dapur & 13 \\
2 & Ruang keluarga & 6 \\
3 & Ruang tamu & 8 \\
4 & Kamar mandi & 0 \\
5 & Teras & 3 \\
\hline
\end{tabular}

Tabel 2. Aktivitas Pengharum Ruangan Minyak Serai Dapur terhadap Koloni Bakteri $S$. aureus di udara

\begin{tabular}{cccccc}
\hline $\begin{array}{c}\text { Titik } \\
\text { penyemprotan }\end{array}$ & $\begin{array}{c}\text { Frekuensi } \\
\text { penyemprotan }\end{array}$ & $\begin{array}{c}\text { Luas } \\
\text { ruangan } \\
\left(\mathbf{m}^{2}\right)\end{array}$ & $\begin{array}{c}\text { Kontrol } \\
(-)\end{array}$ & $\begin{array}{c}\text { Rata- } \\
\text { rata }\end{array}$ & $\begin{array}{c}\text { Penurunan } \\
(\%)\end{array}$ \\
\hline $\begin{array}{c}\text { Dapur } \\
\text { Ruang }\end{array}$ & $1 \mathrm{x}$ & $15 \mathrm{~m}^{2}$ & 15 & 6 & 60 \\
keluarga & & $20 \mathrm{~m}^{2}$ & 9 & 5 & 44 \\
Ruang tamu & & $12 \mathrm{~m}^{2}$ & 3 & 3 & 0 \\
$\quad$ Dapur & & $15 \mathrm{~m}^{2}$ & 15 & 6 & 60 \\
Ruang & $2 \mathrm{x}$ & $20 \mathrm{~m}^{2}$ & 9 & 3 & 67 \\
keluarga & & $12 \mathrm{~m}^{2}$ & 3 & 3 & 0 \\
Ruang tamu & & $15 \mathrm{~m}^{2}$ & 15 & 3 & 80 \\
$\begin{array}{c}\text { Dapur } \\
\text { Ruang }\end{array}$ & $3 \mathrm{x}$ & $20 \mathrm{~m}^{2}$ & 9 & 3 & 67 \\
keluarga & & & & & \\
Ruang Tamu & & $12 \mathrm{~m}^{2}$ & 3 & 3 & 0 \\
\hline
\end{tabular}

Tabel 3. Data uji T dan uji F Aktivitas Pengharum Ruangan Minyak Serai Dapur terhadap Koloni Bakteri S. aureus di udara

\begin{tabular}{|c|c|c|c|c|}
\hline \multicolumn{5}{|c|}{ Data Uji T dan Uji F } \\
\hline $\begin{array}{l}\text { Titik } \\
\text { penyemprotan }\end{array}$ & Variabel bebas & $\mathrm{T}$ & $\mathrm{F}$ & Nilai Sig \\
\hline Dapur & $\begin{array}{l}\text { Frekuensi } \\
\text { penyemprotan }\end{array}$ & 0.083 & 0.183 & $>0.05$ \\
\hline & Lama penyemprotan & 0.631 & & $>0.05$ \\
\hline Ruang keluarga & $\begin{array}{l}\text { Frekuensi } \\
\text { penyemprotan }\end{array}$ & 1000 & 0.105 & $>0.05$ \\
\hline & Lama penyemprotan & 0.041 & & $>0.05$ \\
\hline Ruang tamu & $\begin{array}{c}\text { Frekuensi } \\
\text { penyemprotan } \\
\text { Lama penyemprotan }\end{array}$ & 0.688 & 0.843 & $>0.05$ \\
\hline
\end{tabular}


Tabel 4. Aktivitas Desinfektan terhadap Koloni Bakteri S. aureus di udara

\begin{tabular}{cccccc}
\hline $\begin{array}{c}\text { Titik } \\
\text { penyemprotan }\end{array}$ & $\begin{array}{c}\text { Frekuensi } \\
\text { penyemprotan }\end{array}$ & $\begin{array}{c}\text { Luas } \\
\text { ruangan } \\
\left(\mathbf{m}^{\mathbf{2}}\right)\end{array}$ & $\begin{array}{c}\text { Kontrol } \\
(-)\end{array}$ & $\begin{array}{c}\text { Rata- } \\
\text { rata }\end{array}$ & $\begin{array}{c}\text { Penurunan } \\
(\boldsymbol{\%})\end{array}$ \\
\hline $\begin{array}{c}\text { Dapur } \\
\text { Ruang keluarga }\end{array}$ & $1 \mathrm{x}$ & $15 \mathrm{~m}^{2}$ & 13 & 1 & 92.31 \\
Ruang tamu & & $20 \mathrm{~m}^{2}$ & 6 & 1 & 83.33 \\
Dapur & & $12 \mathrm{~m}^{2}$ & 8 & 3 & 62.50 \\
Ruang keluarga & $2 \mathrm{x}$ & $15 \mathrm{~m}^{2}$ & 13 & 3 & 76.92 \\
Ruang tamu & & $20 \mathrm{~m}^{2}$ & 6 & 4 & 33.33 \\
Dapur & \multirow{2}{*}{$3 \mathrm{x}$} & $12 \mathrm{~m}^{2}$ & 8 & 1 & 87.50 \\
Ruang keluarga & & $15 \mathrm{~m}^{2}$ & 13 & 5 & 61.54 \\
Ruang Tamu & & $20 \mathrm{~m}^{2}$ & 6 & 5 & 16.67 \\
\hline
\end{tabular}

Tabel 5. Data uji T dan uji F Aktivitas desinfektan terhadap Koloni Bakteri S. aureus di udara

\begin{tabular}{|c|c|c|c|c|}
\hline \multicolumn{5}{|c|}{ Uji T dan Uji F } \\
\hline $\begin{array}{l}\text { Titik } \\
\text { penyemprotan }\end{array}$ & Variabel bebas & $\mathrm{T}$ & $\mathrm{F}$ & Nilai Sig \\
\hline \multirow[t]{2}{*}{ Dapur } & Frekuensi & 0.11 & \multirow[b]{2}{*}{0.024} & $>0.05$ \\
\hline & $\begin{array}{l}\text { penyemprotan } \\
\text { Lama penyemprotan }\end{array}$ & 0.271 & & $>0.05$ \\
\hline \multirow[t]{3}{*}{ Ruang keluarga } & Frekuensi & 0.013 & \multirow{3}{*}{0.21} & $>0.05$ \\
\hline & penyemprotan & & & \\
\hline & Lama penyemprotan & 0.107 & & $>0.05$ \\
\hline \multirow[t]{3}{*}{ Ruang tamu } & Frekuensi & 0.349 & \multirow{3}{*}{0.017} & $>0.05$ \\
\hline & penyemprotan & & & \\
\hline & Lama penyemprotan & 0.007 & & $<0.05$ \\
\hline
\end{tabular}

